
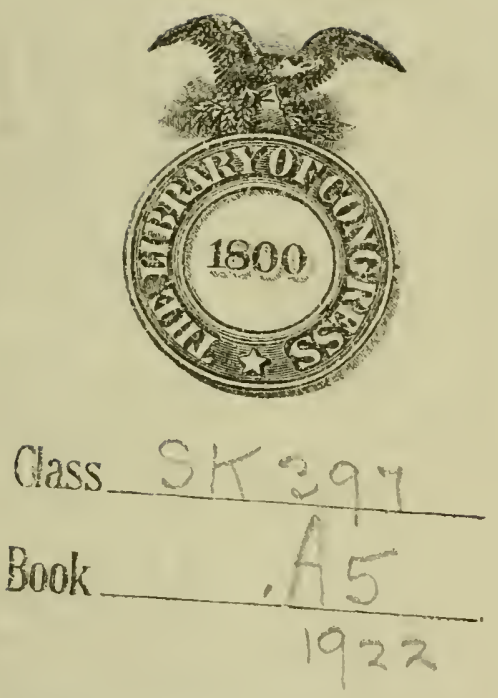


\section{Things You Should Know About}

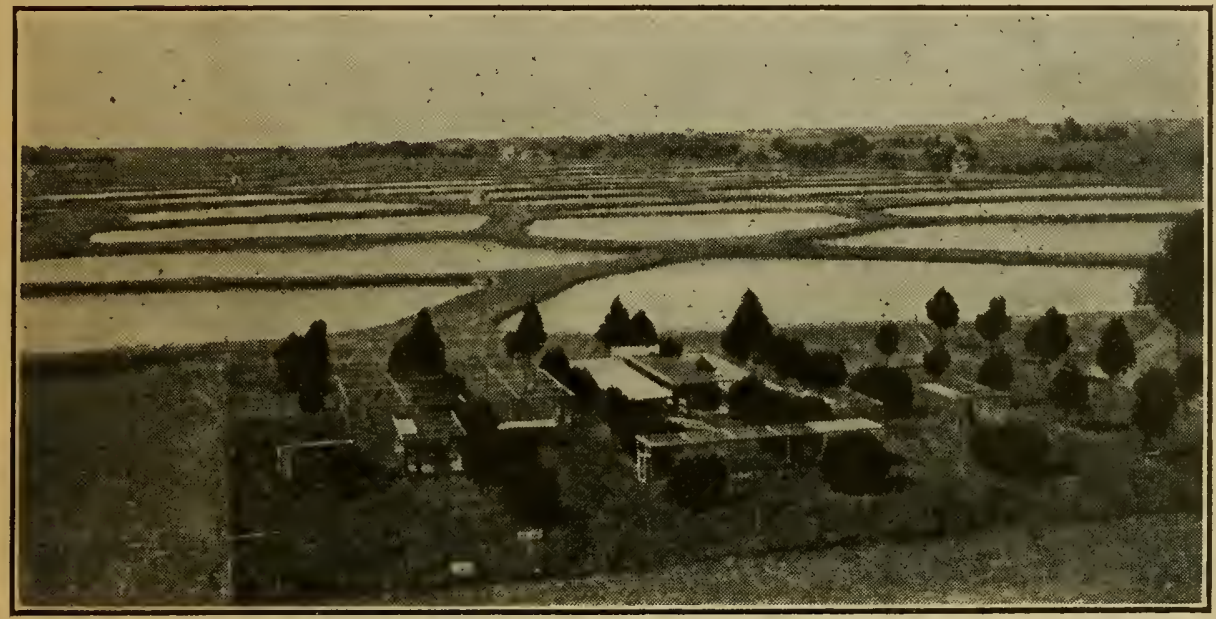

SOME OF THE BROOD PONDS

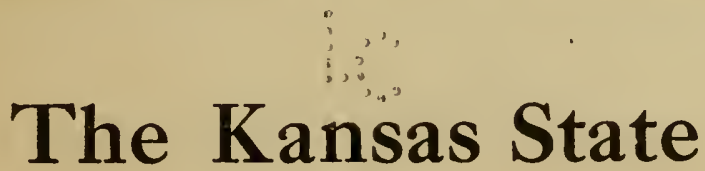

Fish and Game Department PRATT, KANSAS 


\section{THE LOGATION}

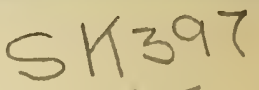

THE HOME of the Kansas Fish and Game Department is at 1 Pratt, Pratt county, where the state owns 187 acres of land on which there are ninety-seven ponds for rearing fish; also seven d́wellings for the warden and his nine employees, an office and aquarium building, power house, barns, ice house, fish house, tools and equipment. The whole plant is in splendid physical condition, beautifully located, and an institution of which Kansans may justly feel proud. Grounds and buildings are electric lighted. The institution could not be reproduced to-day for less than $\$ 300,000$.

A splendid aquarium containing all the native Kansas fish is maintained.

Game birds may be seen in the rearing pens and a deer park is almost completed.

Visitors are welcome at the State Fish Hatchery. A swimming pool is open to the public and patronized by thousands. Picnickers are always present. As many as 240 automobiles loaded with people have visited the hatchery in one day.

The hatchery is two and a half miles east and one mile south of Pratt. It is one mile south of the "Cannon Ball" highway.

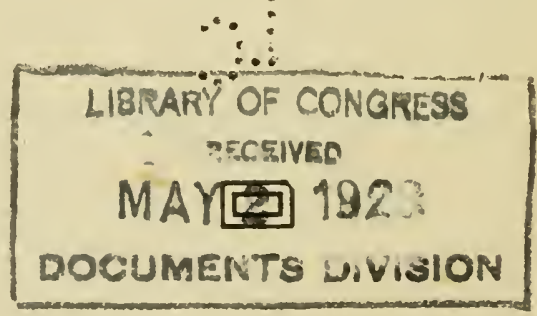




\section{HOW YOU MAY SECURE FISH, GAME BIRDS AND EGGS}

THERE is no charge for anything supplied by this department. What it has and its services are absolutely free to the people of Kansas. In sending out game birds for stocking, we expect the applicant to pay the express on the birds and to return the basket.

Anyone having living water may obtain sufficient young fish to stock same by applying to the department on a form which we will furnish.

We stock private as well as public waters. We give the number and kinds of fish which your description indicates will be best adapted to your water.

The same is true of birds and eggs. They are supplied on application, free to those having suitable food and cover, up to our limit. We never have enough.

We issue bulletins from time to time, of especial interest to hunters and of interest to the public generally. If you would like to receive them, ask that your name-be placed on our mailing list. We shall be glad to send them. If you wish to know about fish culture or how to build a good fish pond, ask for bulletin No. 1. Copies of the game laws are sent on request. We have printed instructions for rearing pheasants, notes about fur farming and much other information about conservation of wild life, which will be sent on request.

Address:

\section{State Fish and Game Department, PRATT, KANSAS.}




\section{DON'T SHOOT}

1. Don'T sноот or trap more than the natural increase of the game in your cover. Your brood stock will soon be wiped out if you do.

2. DoN'т sноот more than the legal limit in any one day, nor that many if you cannot use them.

3. Don'т sноот for your friend's table. Let him kill his own birds.

4. Don't shoot mated or nesting birds. It is equivalent to taking a setting hen off the nest and putting her in the pot.

5. Don'т sноот before the season opens, nor after it closes.

6. Don'т sноот the farmer's poultry or stock. He will then not have to post his land against you.

7. Don't sHоoт yourself or your companion or at anything else until you know exactly what you are shooting at.

8. Don't`shоот unless you have a hunter's license. One fine will pay your annual license for a lifetime.

9. Don't sноот from an automobile or along a public road. The first is unsportsmanlike, the second dangerous.

10. Don't sноот the game warden. He is only doing his duty. 


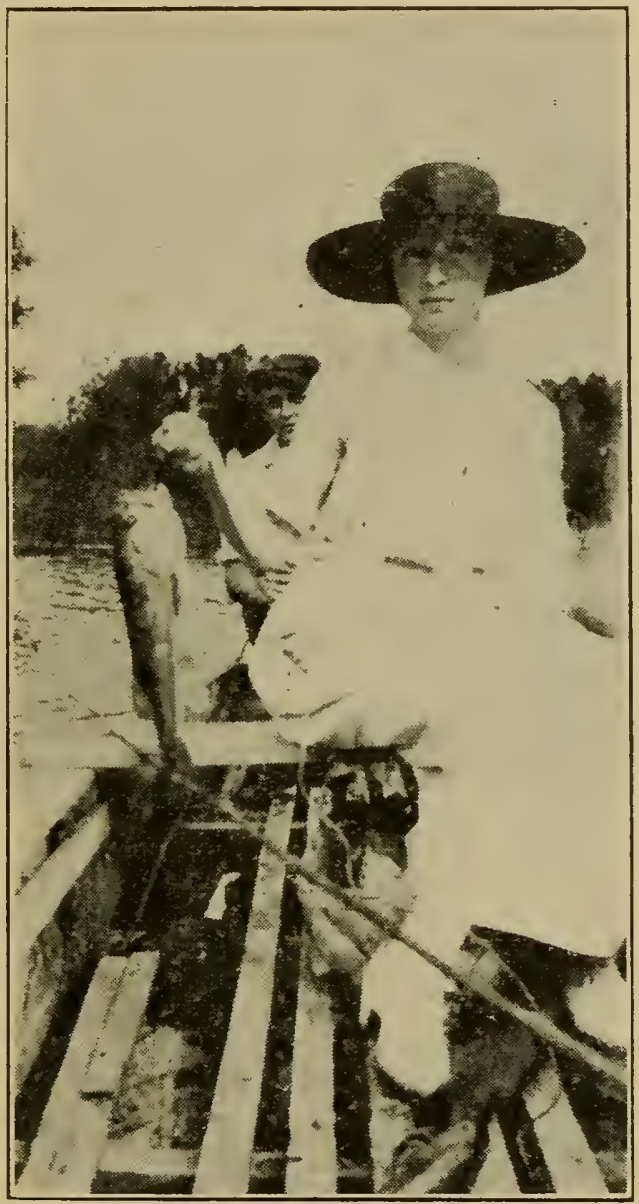

Here is visible proof of what can be done with fish in a made lake. The lake from which this fish was taken was made by damming an ordinary Kansas slough and stocking the impounded water with fish from the State Fish Hatchery. Thousands of fish are caught each year in this lake. It is also one of the best duck lakes in the state. 
THE Kansas Fish and Game Department does not cost the 1 taxpayers of this state one cent. It is supported entirely from the hunters' license fee of $\$ 1$ annually. Individual landowners and their families may hunt on their own land without license.

Not only does it not cost the taxpayer anything, but it paid into the general revenue fund of the state in the last fiscal year about $\$ 3,500$, for under our law five per cent of the gross receipts of the department are diverted into the state treasury to pay for printing, legal advice and the department's share of the running expense of the state. In the same period, the state school fund was enriched to the amount of $\$ 3,104$ from fines paid by violators of the fish and game laws whom this department convicted.

It places annually into the waters of the state about 500,000 fish, and if it were not for the restocking done by this department, there would be very few fish in Kansas waters to-day.

It distributed last year 664 bobwhite quail, 72 blue quail and 300 pheasants for stocking the covers of the state.

Two thousand pheasant and 180 mallard duck eggs were distributed to be hatched, the birds reared and liberated.

Six hundred and six persons were convicted of violating the fish and game laws and 179 illegal devices for taking fish were seized and destroyed in the last year.

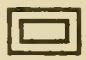




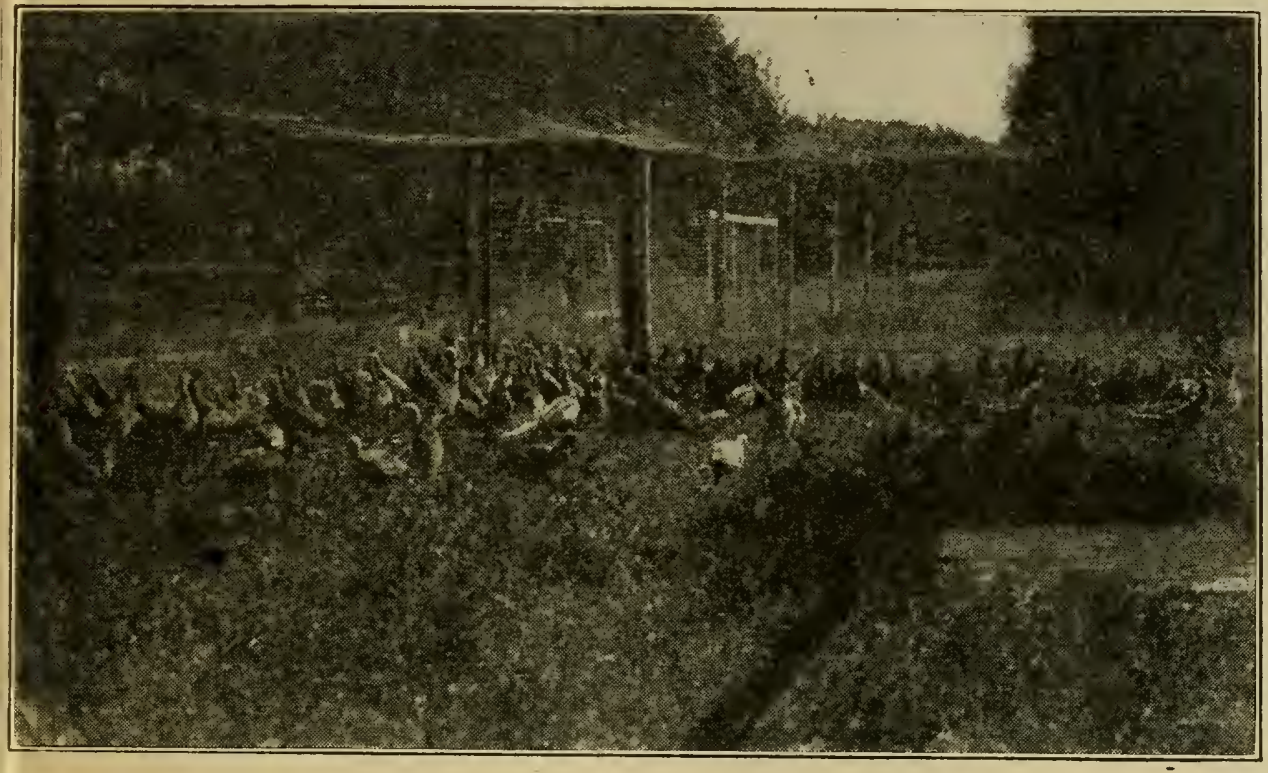

Pheasants reared on the grounds of the State Fish Hatchery.

Pheasants are sent out in the fall only. We use young 1 birds for stocking. Pheasant eggs are sent in the spring. Both on applications only. If interested, write for proper blanks. Applications are filled in the order they are received, all being equal.

Quail are sent out in the spring only. No eggs. The rearing of quail in pens is no job for an amateur.

We never have enough birds or eggs to go round. We supply all we can. 


\section{ORGANIZATION}

Every county in the state should have one or more good live sportsmen's organizations whose first tenet should be the enforcement of the Kansas game laws and next the dissemination of the principles of true conservation. The doctrine of true sportsmanship, of a square deal. Such clubs could educate people to abhor the taking of an unfair advantage of our little wild friends. To kill mated or nesting birds is a crime. This should be brought to the realization and burned into the consciousness of all.

The doctrine of "saving some for seed" needs wide publicity in Kansas, as does the necessity of providing food and cover for our birds.

The right of the farmer to forbid hunting on his land should be recognized and more generally respected. Moderation in killing and a recognition of the principle of killing only the annual increase could be fostered and finally become the governing rule with sportsmen if such clubs were in evidence and would fulfill their mission. Other states have them, why not Kansas?

They would also be of great help to this department in securing just legislation and greatly facilitate its labor in the distribution of game birds and eggs for restocking. Such stocking would be more effective if managed by local bodies, as they would know local conditions as the department cannot know them. I appeal to every man who loves to hunt and fish to organize a sportsman's club in your neighborhood. 

LIBRARY OF CONGRESS . 00028995143 